\title{
PEMBERDAYAAN MASYARAKAT DALAM MENINGKATKAN SARANA SANITASI RUMAH TANGGA (JAMBANISASI) DI DESA BINAAN MARGOAGUNG KECAMATAN JATIMULYO LAMPUNG SELATAN
}

\section{Sutarto $^{1)}$, Minerva Nadia Putri A.T ${ }^{1)}$, Dian Isti Angraini ${ }^{1)}$, Sofyan Musyabiq Wijaya ${ }^{1)}$, Dyah Wualn Sumekar Rengganis Wardani ${ }^{1)}$, Hamdi Nasution ${ }^{1)}$}

\author{
${ }^{1)}$ Fakultas Kedokteran, Universitas Indonesia, sutarto@fk.unila.ac.id \\ ${ }^{1)}$ Fakultas Kedokteran, Universitas Indonesia, minervanadiaputri@ gmail.com \\ ${ }^{1)}$ Fakultas Kedokteran, Universitas Indonesia, riditie@gmail.com \\ ${ }^{1)}$ Fakultas Kedokteran, Universitas Indonesia, obiqwijaya@ gmail.com \\ ${ }^{1)}$ Fakultas Kedokteran, Universitas Indonesia, dwwardani@yahoo.com \\ ${ }^{1)}$ Fakultas Kedokteran, Universitas Indonesia, hamiditwins@gmail.com
}

\begin{abstract}
ABSTRAK
Kondisi lingkungan yang sangat berpengaruh terhadap derajat kesehatan diantaranya adalah penyediaan air bersih, jamban keluarga, kondisi rumah dan kondisi lingkungan pemukiman. Sanitasi yang tidak memadai merupakan penyebab utama timbulnya penyakit.Upaya pemberdayaan masyarakat untuk meningkatkan sarana sanitasi rumah tangga (jambanisasi) memiliki dampak yang sangat positif pada kesehatan di lingkungan rumah tangga dan masyarakat. Pengabdian ini adalah kegiatan yang terdiri dari penyuluhan tentang jamban yang sehat di desa Marga Agung Kecamatan Jati Agung Lampung Selatan. Kegiatan ini bertujuan untuk meningkatkan pengetahuan masyarakat akan pentingnya sanitasi di dalam rumah tangga. Pengabdian ini menggunakan metode ceramah penyuluhan, evaluasi kegiatan dilakukan denhan penilaian pengetahuan peserta dengan memberikan pre-post test. Hasil dari pengabdian ini masyarakat mampu mengidentifikasi dan memilih jenis jamban yang tepat untuk digunakan. Masyarakat diharapkan mampu mengidentifikasi ciri-ciri jamban yang tidak sehat. Berdasarkan hasil evauasi terjadi peningkatan pengetahuan masyarakat tentang jamban sehat dengan peningkatan poin sebesar 10,4 poin setelah dilakukan pengabdian. Kegiatan ini merupakan bagian upaya untuk meningkatkan cakupan jamban sehat.
\end{abstract}

Kata Kunci : Pemberdayaan Masyarakat, Sanitasi, Jamban

\section{ABSTRACT}

Environmental conditions that are very influential on health status include the provision of clean water, family latrines, housing conditions and residential conditions. Inadequate sanitation is a major cause of disease. Efforts to empower the community to improve household sanitation facilities (jambanisasi) have a very positive impact on health in the household and community environment. This service is an activity consisting of counseling about healthy latrines in the village of Marga Agung, Jati Agung Subdistrict, South Lampung. This activity aims to increase public knowledge of the importance of sanitation in the household. This service uses the counseling lecture method, activity evaluation is carried out by evaluating the participants' knowledge by giving a prepost test. As a result of this service, the community is able to identify and choose the right type of toilet to use. The community is expected to be able to identify the characteristics of unhealthy latrines. Based on the results of the evaluation, there was an increase in community knowledge about healthy latrines with an increase of 10.4 points after dedication. This activity is part of an effort to increase the coverage of healthy latrines.

Keywords: Community Empowerment, Sanitation, Latrines 
PENDAHULUAN

Sanitasi sebagai salah satu aspek pembangunan memiliki fungsi penting dalam menunjang tingkat kesejahteraan masyarakat, karena berkaitan dengan kesehatan, pola hidup, kondisi lingkungan permukiman serta kenyamanan dalam kehidupan sehari-hari (Ditjen PP \& PL, 2013).

Derajat kesehatan dipengaruhi oleh banyak faktor yaitu: lingkungan, perilaku, pelayanan kesehatan dan keturunan. Faktor lingkungan dan perilaku sangat mempengaruhi derajat kesehatan. Termasuk lingkungan yaitu keadaan pemukiman atau perumahan, tempat kerja, sekolah dan tempat umum, air dan udara bersih, teknologi, pendidikan, sosial dan ekonomi. Sedangkan perilaku tergambar dalam kebiasaan sehari-hari seperti pola makan, kebersihan perorangan, gaya hidup, dan perilaku terhadap upaya kesehatan (Depkes, 2009). Dalam hal sanitasi lingkungan, masyarakat masih memanfaatkan "toilet terbuka" yang biasanya terletak di kebun, pinggir sungai, dan parit sawah. Melakukan buang air besar di tempat terbuka akan menimbulkan pencemaran pada permukaan tanah dan air. Perilaku semacam itu dipengaruhi oleh beberapa faktor, antara lain faktor ekonomi karena untuk membuat septik tank diperlukan biaya, tidak tersedianya septik tank umum dan layanan yang baik untuk penyedotannya. Karena beberapa faktor tersebut, maka muncullah suatu masalah yaitu adanya masyarakat yang masih buang air besar di sembarang tempat (Sholikhah, S. 2014).
Menurut data UNICEF, 44,5\% total seluruh penduduk Indonesia belum memiliki akses pembuangan tinja yang layak dan 63 juta masyarakat Indonesia masih buang air besar sembarangan atau $24 \%$ dari total penduduk Indonesia pada tahun 2012 masih melakukan buang air besar (BAB) Sembarangan. Lebih lanjut, UNICEF menyatakan bahwa sanitasi dan perilaku kebersihan yang buruk, serta minum air yang tidak aman berkontribusi terhadap $88 \%$ kematian anak akibat diare diseluruh dunia (Triyono, A. 2014).

Sanitasi yang baik dapat mengurangi penularan mikroba yang menyebabkan diare dengan cara mencegah kontaminasi tinja manusia dengan lingkungan. Meningkatnya sarana sanitasi dapat mengurangi insiden diare sebesar 36 \%. (Unicef, 2009). Penggunaan jamban efektif dapat mengurangi insiden penyakit diare sebesar 30\% (Semba R, Kraemer , K, Sun, K. et.al, 2011). Di Provinsi Lampung sendiri pada tahun 2012 kepemilikan sanitasi dasar berupa jamban sehat hanya sebesar $53,33 \%$, masih menjauhi target yang diharapkan (Dinkes Provinsi, 2012).

Menurut laporan penyebab terjadinya kurangnya cakupan kepemilikan sanitasi dasar (jamban) dikarenakan kurangnya pemahaman masyarakat akan pentingnya sanitasi dan jamban yang sehat serta faktor ekonomi. Hal tersebut menjadikan pentingnya pemberdayaan masyarakat untuk meningkatkan sarana sanitasi rumah tangga (jambanisasi). 
METODE KEGIATAN

Pengabdian ini menggunakan metode ceramah penyuluhan. Metode ceramah merupakan metode yang baik untuk sasaran yang berpendidikan tinggi maupun rendah (Notoatmodjo, 2010). Penyuluhan merupakan penyampaian pesan, sehingga sasaran dapat meningkat pengetahuannya yang akhirnya diharapkan dapat berubah perilakunya kearah positif terhadap kesehatan (Lucie, S, 2005).

Pengabdian ini terdiri dari kegiatan penyuluhan mengenai sanitasi kesehatan dan rumah tangga, jenis jamban, ciri-ciri jamban sehat, penyakit akibat sanitasi buruk serta pencegahan terhadap penyakit akibat sanitasi rendah,dilanjutkan sesi diskusi dengan peserta dan terakhir evaluasi kegiatan (pre-post test). Alat yang digunakan adalah laptop, LCD dan proyektor untuk dapat menampilkan materi kepada peserta penyuluhan, serta kertas soal dan alat tulis untuk pre dan post test.

Sasaran dari kegiatan ini adalah seluruh masyarakat di Desa Marga Agung, Kecamatan Jati Agung, Lampung Selatan. Kegiatan Evaluasi dilakukan dengan melihat hasil dari pre test dan post test.

\section{HASIL DAN PEMBAHASAN}

Pemberdayaan Masyarakat dalam Meningkatkan Sarana Sanitasi Rumah Tangga (jambanisasi) adalah kegiatan yang terdiri dari penyuluhan tentang sanitasi dan jamban sehat. Kegiatan ini dilakukan di Balai Desa Marga Agung Kecamatan Jati Agung Lampung Selatan yang dihadiri oleh Bapak Lurah, Bapak Sekertaris Desa, Kader serta Bapak dan Ibu
Masyarakat Marga Agung Kecamatan Jati Agung Lampung Selatan. Kegiatan penyuluhan jamban sehat ini dilaksanakan pada hari Rabu, 24 Oktober 2018. Kegiatan ini dimulai jam 08.30 - 13.30 WIB. Jumlah peserta yang hadir pada kegiatan ini adalah 30 orang peserta yang tersebar dari enam dusun. Kegiatan pertama diawali dengan penyuluhan, dilanjutkan dengan sesi diskusi peserta dan diakhiri dengan evaluasi. Untuk mengetahui tingkat keberhasilan penyuluhan, dilakukan evaluasi dengan melakukan pre test pada sebelum penyuluhan dan post test yang diberikan setelah penyuluhan dilakukan.

Tabel 1. Hasil Test Penyuluhan Jamban Sehat

\begin{tabular}{ccc}
\hline Test & Rerata Nilai Test \\
\hline$\bullet$ & Pre Test & 89,6 \\
\hline$\bullet$ & Post Test & 100 \\
\hline
\end{tabular}

Dari hasil evaluasi didapatkan bahwa terdapat peningkatan nilai rerata post test dibandingkan pre test yang dilakukan sebelum penyuluhan. Hal ini menjelaskan bahwa terdapat peningkatan pengetahuan masyarakat mengenai jamban sehat. Pada saat kegiatan berlangsung jumlah masyarakat yang hadir sebanyak 30 orang sehingga pre test diikuti oleh 30 orang. Hasil jawaban pre test rata-rata bernilai 89,6 .

Selama proses kegiatan berlangsung masyarakat terlihat sangat antusias, hal ini ditunjukan saat sesi diskusi, banyak peserta yang bertanya terkait jamban sehat. Kemudian dilakukan pengukuran pengetahuan kembali (post test) kepada peserta, hasil post test 
didapatkan rata-rata nilai adalah 100, yang berarti semua peserta penyuluhan mampu menjawab seluruh pertanyaan dengan benar. Hal ini menunjukkan peningkatan pengetahuan masyarakat tentang jamban sehat dengan peningkatan poin sebesar 10,4 poin. Berdasarkan penjelasan di atas terdapat peningkatan pengetahuan masyarakat mengenai jamban sehat, sehingga kegiatan penyuluhan dianggap berhasil meningkatkan pengetahuan peserta.

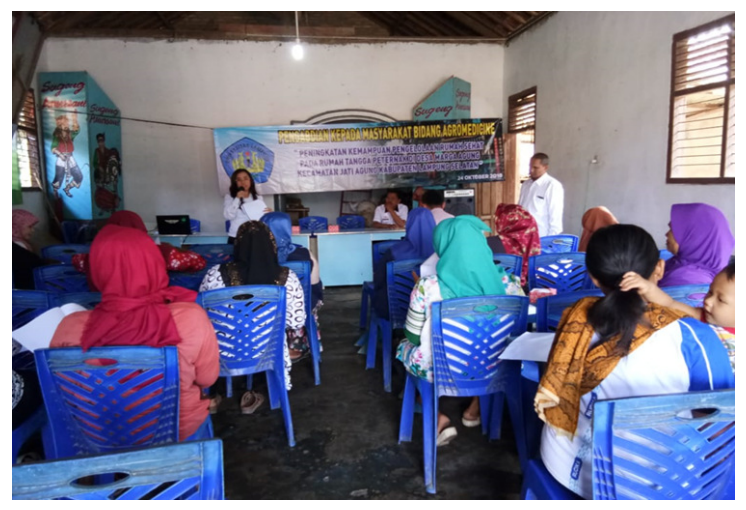

Gambar 1 . Penyuluhan Jamban Sehat

\section{KESIMPULAN}

Setelah mendapatkan penyuluhan tentang jamban sehat melalui Pemberdayaan Masyarakat untuk meningkatkan sarana sanitasi rumah tangga (jambanisasi) maka pengetahuan masyarakat di Desa Binaan Margoagung Kecamatan Jatimulyo Lampung Selatan menjadi meningkat. Penilaian ini berdasarkan hasil pre dan post test yang mengalami peningkatan sebesar 10,4 poin.

\section{DAFTAR PUSTAKA}

Ditjen PP \& PL, Kemenkes RI, (2013). Road Map Percepatan Program STBM Tahun 2013-2015, Jakarta.

Departemen Kesehatan Republik Indonesia. 2009. Pedoman Teknik Penyehatan
Perumahan Jakarta : Depertemen Kesehatan RI -Direktorat Jendral PPM \& PL. Departemen Kesehatan Republik Indonesia 2009. Profil kesehatan Indonesia 2008. Jakarta : Depkes RI.

Sholikhah, S. 2014. Hubungan Pelaksanaan Program ODF (Open Defecation Free) Dengan Perubahan Perilaku Masyarakat Dalam Buang Air Besar Di Luar Jamban Di Desa Kemiri Kecamatan Malo Kabupaten Bojonegoro Tahun 2012, Surya Vol.02, No.XVIII, Juni 2014

Triyono, A. 2014. Faktor - Faktor yang Berhubungan dengan Perilaku Buang Air Besar Masyarakat Nelayan di Kampung Garapan Desa Tanjung Pasir Kabupaten Tangerang Propinsi Banten . Forum Ilmiah Volume 11 Nomor 3, September 2014

UNICEF/WHO. 2009. Diarrhoea: Why children are still dying and what can be done: $1-15$.

Semba R, Kraemer , K, Sun , K. et.al. 2011. Relationship of the Presence of a Household Improved Latrine with Diarrhea and Under- Five Child Mortality in Indonesia. The American Society of Tropical Medicine and Hygiene. 84(3)443-50.Dinkes Provinsi, 2012

Notoatmodjo. Metodologi Penelitian Kesehatan. Jakarta: Rineka Cipta; 2010

Lucie, S. Teknik Penyuluhan dan Pemberdayaan Masyarakat. Bogor: Penerbit Ghalia Indonesia; 2005 